\title{
Synthesis and Structural Studies of 4-Thioxopyrimidines with Antimicrobial Activities
}

\author{
Silvio Cunha ${ }^{1, *}$, Rodrigo M. Bastos ${ }^{1}$, Priscila de O. Silva ${ }^{1}$, Giselle A. Nobre Costa ${ }^{1}$, \\ Ivo Vencato $^{2,3}$, Carlito Lariucci ${ }^{2}$, Hamilton B. Napolitano ${ }^{3}$, Cecília M. A. de Oliveira ${ }^{4}$,

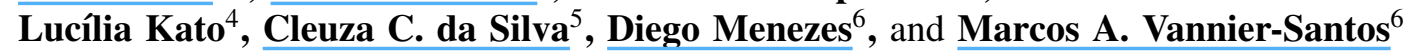 \\ 1 Instituto de Química, Universidade Federal da Bahia, Campus de Ondina, Salvador-BA, Brazil \\ 2 Instituto de Física, Universidade Federal de Goiás, Goiânia-GO, Brazil \\ 3 Ciências Exatas e Tecnológicas, Universidade Estadual de Goiás, Anápolis-GO, Brazil \\ 4 Instituto de Química, Universidade Federal de Goiás, Goiânia-GO, Brazil \\ 5 Departamento de Química, Universidade Estadual de Maringá, Maringá-PR, Brazil \\ ${ }^{6}$ Laboratório de Biomorfologia Parasitária e Microscopia Eletrônica, Centro de Pesquisas Gonçalo Moniz, \\ Fundação Oswaldo Cruz (CPqGM-FIOCRUZ), Candeal, Salvador-BA, Brazil
}

Received June 19, 2006; accepted (revised) July 13, 2006; published online January 19, 2007

(C) Springer-Verlag 2007

\begin{abstract}
Summary. This work describes a two-step, one-pot synthetic method for the formal aza-[3+3] cycloaddition between $\mathrm{N}$-alkyl substituted enaminones and benzoyl isothiocyanate, which afforded 4-thioxopyrimidines in reasonable yields. Reaction of acyclic enaminone with a sterically hindered group attached to the nitrogen atom afforded pyridine-2thione, yet in low yield. The antibacterial, antifungal, and trypanocidal activities of the thioxopyrimidines were evaluated and five compounds exhibited moderate activity against Candida albicans, Micrococcus luteus, and Trypanosoma cruzi. The solid state structures of a thioxopyrimidine, an organic disulfide, and a 1,2,4-triazole were determined by $\mathrm{X}$-ray diffraction analysis.
\end{abstract}

Keywords. Cyclizations; Enaminones; Heterocycles; Pyrimidine-4-thiones; X-ray structure determination.

\section{Introduction}

Thioxopyrimidine is an essential structural unit of several heterocycles, which displays a wide range of interesting biological and pharmacological properties, such as anticancer and antimicrobial activities [1]. Despite these characteristics there are few synthet-

\footnotetext{
* Corresponding author. E-mail: silviodc@ufba.br
}

ic methodologies for this class of heterocycles [2]. Among them, the formal aza-[3+3] cycloaddition involving enaminones as synthons for the preparation of the bioactive heterocyclic nucleus [3] caught our attention because enaminones are easily prepared in good yields and have been used in the synthesis of a broad spectrum of compounds [4]. However, while thioxopyrimidine synthesis is well described with $\mathrm{N}$-aryl substituted enaminones and isothiocyanates $[2,5]$, very little is known about the scope of this aza-annulation with monosubstituted $N$-alkyl enaminones, including sterically hindered ones, as the nucleophilic component in the synthesis of thioxopyrimidines via formal aza-[3+3] cycloaddition.

According to Hsung et al., the formation of heterocycle cores from an enaminone can be envisioned as a formal aza- $[3+3]$ cycloaddition between an enaminone and a functionalized $\alpha, \beta$-unsaturated carbonyl electrophile (or its equivalent), Fig. 1. The regiochemistry of this stepwise process can be classified according to the orientation of carbonyl moieties of enaminone and electrophile. The head-to-head regiochemistry (Hsung's aza-annulation [3a]) results from the orientation of both carbonyl carbons at the 


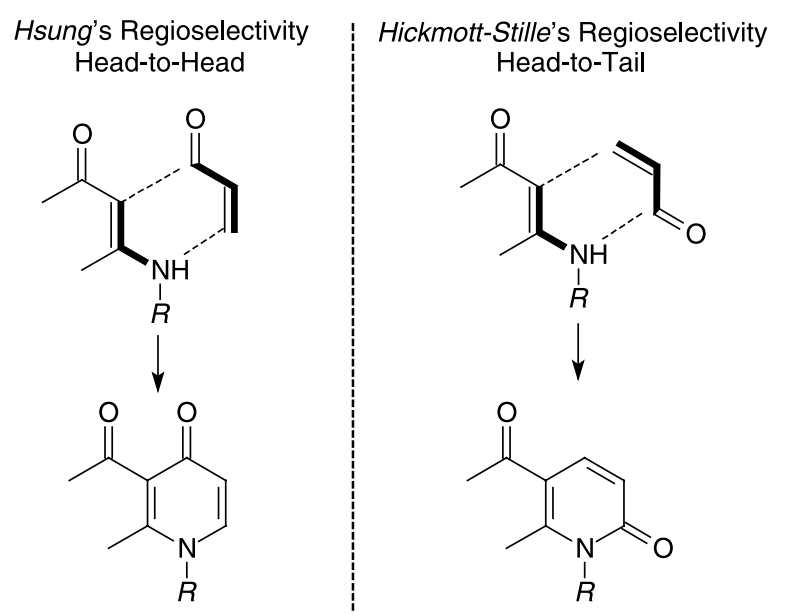

Fig. 1. Regiochemistry of formal aza- $[3+3]$ cycloaddition of enaminones and a generic $\alpha, \beta$-unsaturated carbonyl eletrophile

same side, whereas the head-to-tail regiochemistry (Hicmott-Stille's aza-annulation [3b, 3c]) arises from carbonyl carbons oriented at opposite sides [3d, 3e].

Herein we disclose our results concerning the formal aza-[3+3] cycloaddition of acyclic $N$-alkyl substituted enaminones with benzoyl isothiocyanate for a direct 4-thioxopyrimidine synthesis with emphasis on synthetic, mechanistic, and structural implications.

\section{Results and Discussion}

We were unable to reproduce the yields of thioxopyrimidines $\mathbf{4 a - 4 b}$ using the reported protocol [5a, 5h]. Thus, a systematic investigation of the reaction conditions for the formal aza-[3+3] cycloaddition was undertaken. Attempts to optimize the reaction conditions revealed that the formation and yields of heterocycles $\mathbf{4 a}-\mathbf{4 b}$ were dependent of solvent, temperature, and the nature of enaminone employed. In the best condition, 4a was obtained at room temperature from $\beta$-enamino ketone 1a and benzoyl isothiocyanate (2) using isopropyl ether as solvent in $30 \%$ yield. On the other hand, $\beta$-enamino ester $\mathbf{1 b}$ afforded $\mathbf{4 b}$ in better yield (72\%), but with a twostep one-pot procedure (first, ethyl ether as solvent and reaction at $0-5^{\circ} \mathrm{C}$; second, solvent exchange for ethyl alcohol and reaction at room temperature) according to Scheme 1. Formation of thioxopyrimidines $\mathbf{4 a}-\mathbf{4 b}$ proceeded via acyclic intermediates $\mathbf{3 a}-\mathbf{3 b}$ as has been previously observed [5a, 5c]. The reaction progress was easily followed because the solution turned red, the typical color of the intermediates $\mathbf{3 a}$ and $\mathbf{3 b}$. Besides, formation of the $\mathrm{C}$-adduct $\mathbf{3 a}$ and not the regioisomeric $\mathrm{N}$-adduct has been corroborated by absence of olefinic $\mathrm{C}-\mathrm{H}$ in both ${ }^{1} \mathrm{H}$ and ${ }^{13} \mathrm{C}$ NMR spectra [6].

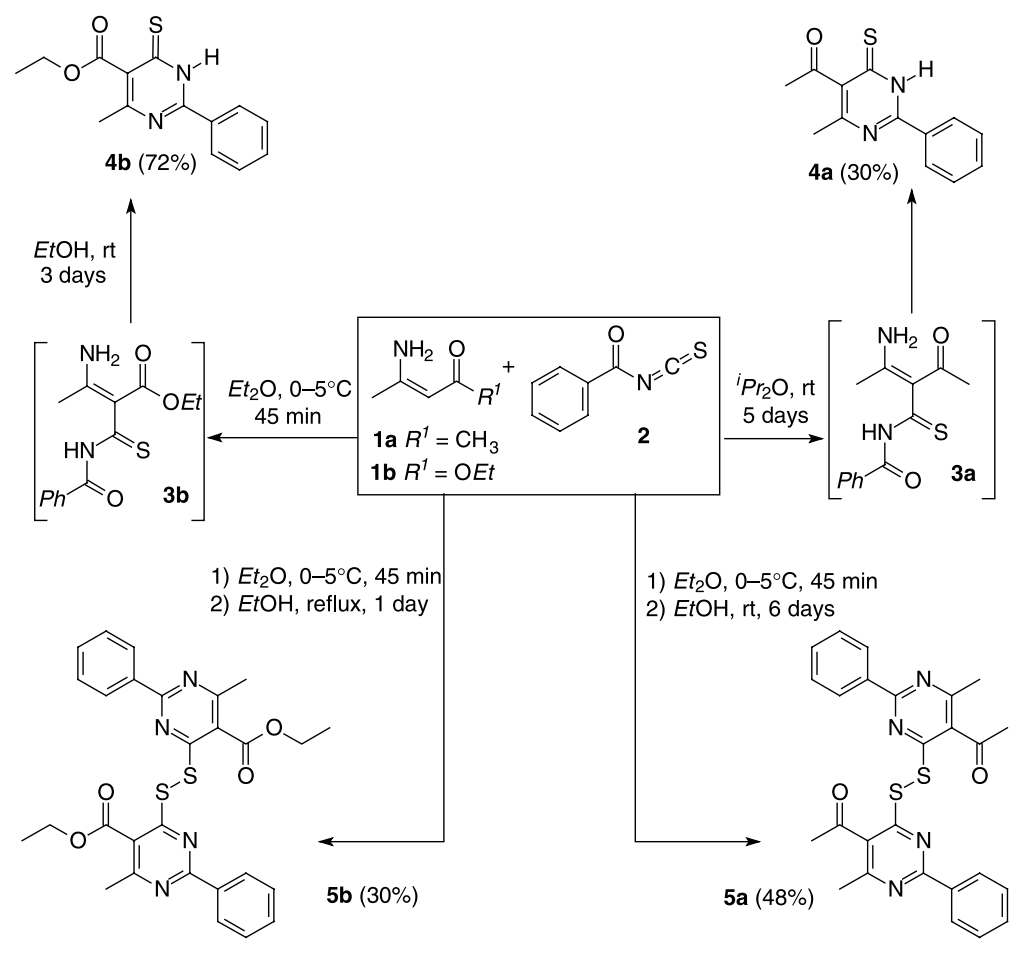

Scheme 1 
Because the two-step one-pot procedure affords the best yields, it was extended to the $\beta$-enamino ketone 1a, but a slow reaction took place. After consumption of 3a [7] the disulfide 5a was the sole product, Scheme 1. Additionally, attempts to optimize the yield of $\mathbf{4 b}$ by refluxing in the second step failed. Only the disulfide $\mathbf{5 b}$ was isolated in low yield, Scheme 1. Formation of disulfides $\mathbf{5 a - 5} \mathbf{b}$ proceeded via $\mathbf{4 a}-\mathbf{4 b}[5 \mathrm{a}, 5 \mathrm{c}]$. Noteworthy, a previous study reported that the synthesis of $\mathbf{5 a}-\mathbf{5 b}$ via $\mathbf{4 a}-\mathbf{4 b}$ took place only under basic conditions [5c]. Herein, the spontaneous conversion under base-free conditions suggests that $\mathbf{4 a - 4 b}$ undergo air oxidation to $\mathbf{5 a}-\mathbf{5 b}$, probably via reversible transformation because, when disulfide $\mathbf{5 a}$ was left in $\mathrm{CDCl}_{3}$ in the NMR tube it was slowly converted into thioxopyrimidine $\mathbf{4 a}$, and the ratio of $\mathbf{5 a}: \mathbf{4 a}$ after two days was $1.5: 1$, according to the integral of methyl groups in the ${ }^{1} \mathrm{H}$ NMR spectrum.

Although thioxopyrimidines $\mathbf{4 a}-\mathbf{4 b}$ and disulfides $\mathbf{5 a}-\mathbf{5 b}$ are known compounds $[5 \mathrm{a}, 5 \mathrm{c}]$ we wanted to corroborate their structure unambiguously. Thus we undertook the structural characterization by an X-ray study of $\mathbf{4 b}$ and $\mathbf{5 a}-\mathbf{5 b}$, which afforded monocrystals. The ORTEP [8] representation of the solid state

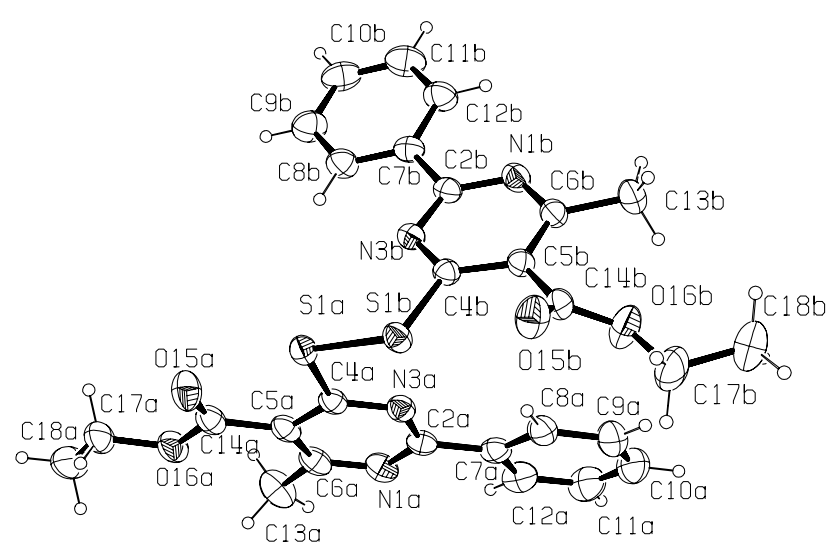

Fig. 2. ORTEP drawing of disulfide $\mathbf{5 b}$ with atom-numbering scheme; the displacement ellipsoids are drawn at $30 \%$ probability levels

structures of $\mathbf{5 b}$ is shown in Fig. 2 as an example (for 4b vide infra). The only structural difference between $\mathbf{5 a}$ and $\mathbf{5 b}$ is the $\mathrm{C} 5$ substituent of pyrimidine rings, but they presented significant different features. Thus, disulfide 5a is a planar molecule in the solid state with pyrimidine rings antiperiplanar at the $\mathrm{S}-\mathrm{S}$ bond (torsional angle $\mathrm{C} 4-\mathrm{S}-\mathrm{S}^{i}-\mathrm{C}^{i}=180^{\circ}$, symmetry code: (i) $=-x+1,-y+1,-z$ ). Curiously, this conformation is not observed in $\mathbf{5 b}$, where the

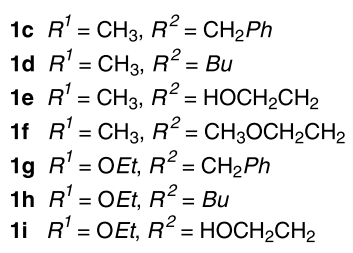<smiles>CCCCc1c(C)n(CCOC(C)=O)c(-c2ccccc2)nc1=S</smiles>$$
\begin{gathered}
A c_{2} \mathrm{O} \\
\text { Pyridine } \\
D M F, \text { rt }
\end{gathered} \mid \begin{aligned}
& R^{1}=\mathrm{CH}_{3}, \mathbf{4 j}(90 \% \text { from } \mathbf{4 e}) \\
& R^{1}=\mathrm{O} E t, \mathbf{4 k}(85 \% \text { from } 4 \mathbf{i})
\end{aligned}
$$

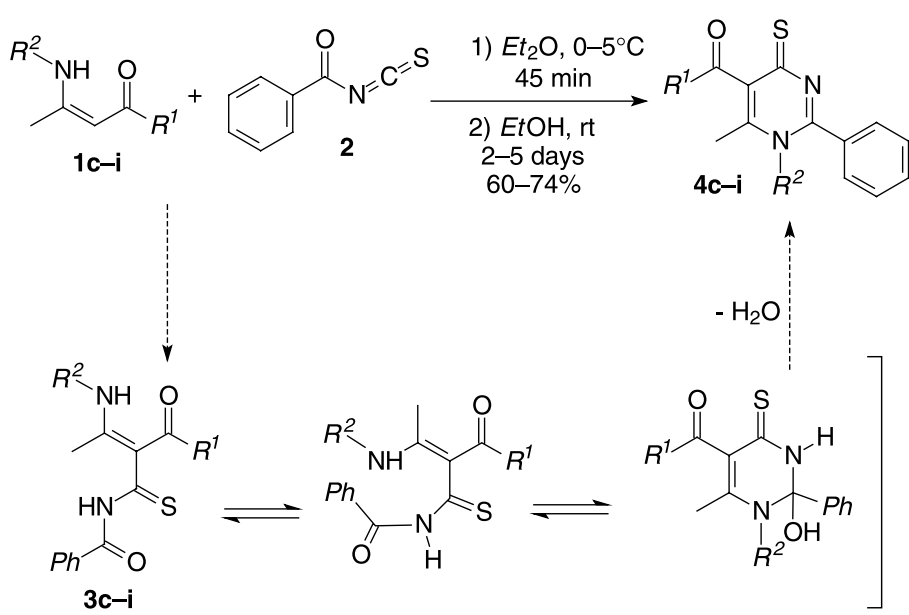

Scheme 2 
corresponding torsional angle C4a-S1a-S1b-C4b is $75.99(7)^{\circ}$, with the pyrimidines positioned synclinal.

In order to investigate the scope and limitations of formal aza-[3+3] cycloaddition a series of structurally different enaminones was subjected to reaction with benzoyl isothiocyanate (2). Acyclic $N$-alkyl substituted $\beta$-enamino ketones $\mathbf{1 c}-\mathbf{1 f}$ and $\beta$-enamino esters 1 g-1i were submitted to the two-step one-pot condition, Scheme 2. Thus, a series of new 4-thioxopyrimidines $\mathbf{4 c}-\mathbf{4 i}$ could be obtained in reasonable yields from enaminones owing to a primary alkyl group connected to the nitrogen atom, Table 1.

Mechanistically, the formation of $\mathrm{N}$-alkyl 4-thioxopyrimidines $\mathbf{4} \mathbf{c}-\mathbf{4 i}$ can be envisioned as an ionic

Table 1. Isolated yields and $I C_{50}$ of anti-Trypanosoma cruzi activity of 4-thioxopyrimidines

\begin{tabular}{cllccc}
\hline Compound & $R^{1}$ & \multicolumn{1}{c}{$R^{2}$} & Yield $/ \%$ & Time $/ \mathrm{d}$ & $\begin{array}{c}I C_{50} \\
(\mu M)\end{array}$ \\
\hline $\mathbf{4 c}$ & $\mathrm{CH}_{3}$ & $\mathrm{CH}_{2} \mathrm{Ph}$ & 72 & 5 & 159.9 \\
$\mathbf{4 d}$ & $\mathrm{CH}_{3}$ & $\mathrm{Bu}$ & 70 & 4 & 95.4 \\
$\mathbf{4 e}$ & $\mathrm{CH}_{3}$ & $\mathrm{CH}_{2} \mathrm{CH}_{2} \mathrm{OH}$ & 65 & 5 & 148.2 \\
$\mathbf{4 f}$ & $\mathrm{CH}_{3}$ & $\mathrm{CH}_{2} \mathrm{CH}_{2} \mathrm{OCH}$ & 60 & 2 & $\mathrm{nt}^{\mathrm{a}}$ \\
$\mathbf{4 g}$ & $\mathrm{OEt}^{\mathrm{a}}$ & $\mathrm{CH}_{2} \mathrm{Ph}$ & 74 & 2 & $\mathrm{nt}^{\mathrm{a}}$ \\
$\mathbf{4 h}$ & $\mathrm{OEt}$ & $\mathrm{Bu}_{4}$ & 73 & 2 & 99.0 \\
$\mathbf{4 i}$ & $\mathrm{OEt}$ & $\mathrm{CH}_{2} \mathrm{CH}_{2} \mathrm{OH}$ & 66 & 5 & 153.3 \\
\hline
\end{tabular}

${ }^{\mathrm{a}} n t$ Not tested stepwise process (Scheme 2) initiated by attack of the nucleophilic $\alpha$ carbon of the enaminone to the electrophilic sp hybridized carbon of 2 , which represents a soft-soft interaction, yielding $\mathrm{C}$-adducts 3c-3i. In sequence, $\mathbf{3 c - 3 i}$ suffer an intramolecular $\mathrm{N}$-acylation and elimination of water. The regioselectivity of this formal aza- $[3+3]$ cycloaddition corresponds to the head-to-tail regiochemistry (HicmottStille's aza-annulation, Fig. 1) [3d, 3e]. The structures of compounds $4 \mathbf{b}, \mathbf{4 e}, \mathbf{4 h}$, and $4 \mathbf{i}$ were also investigated by means of an X-ray analysis and an

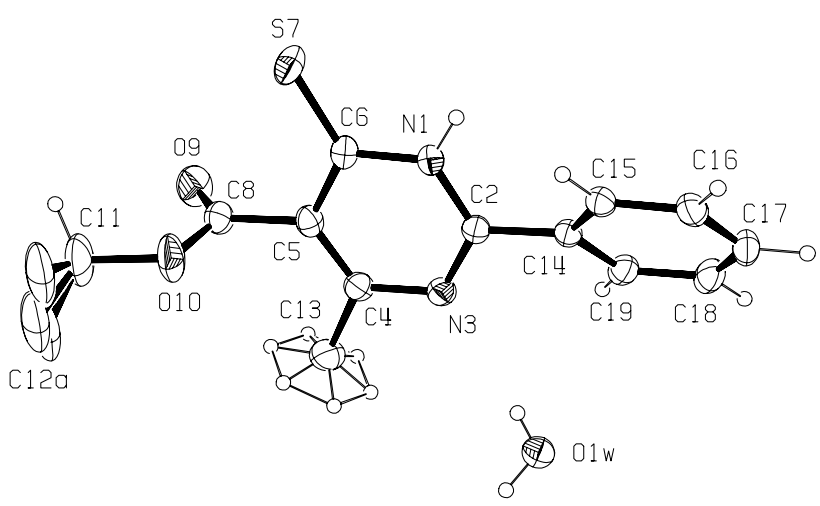

Fig. 3. ORTEP drawing of $\mathbf{4 b}$ with atom-numbering scheme; the $\mathrm{C} 12$ atom is disordered and its $\mathrm{H}$-atoms were not found; the $\mathrm{H}$-atoms of C13-methyl are also disordered; the displacement ellipsoids are drawn at $30 \%$ probability levels

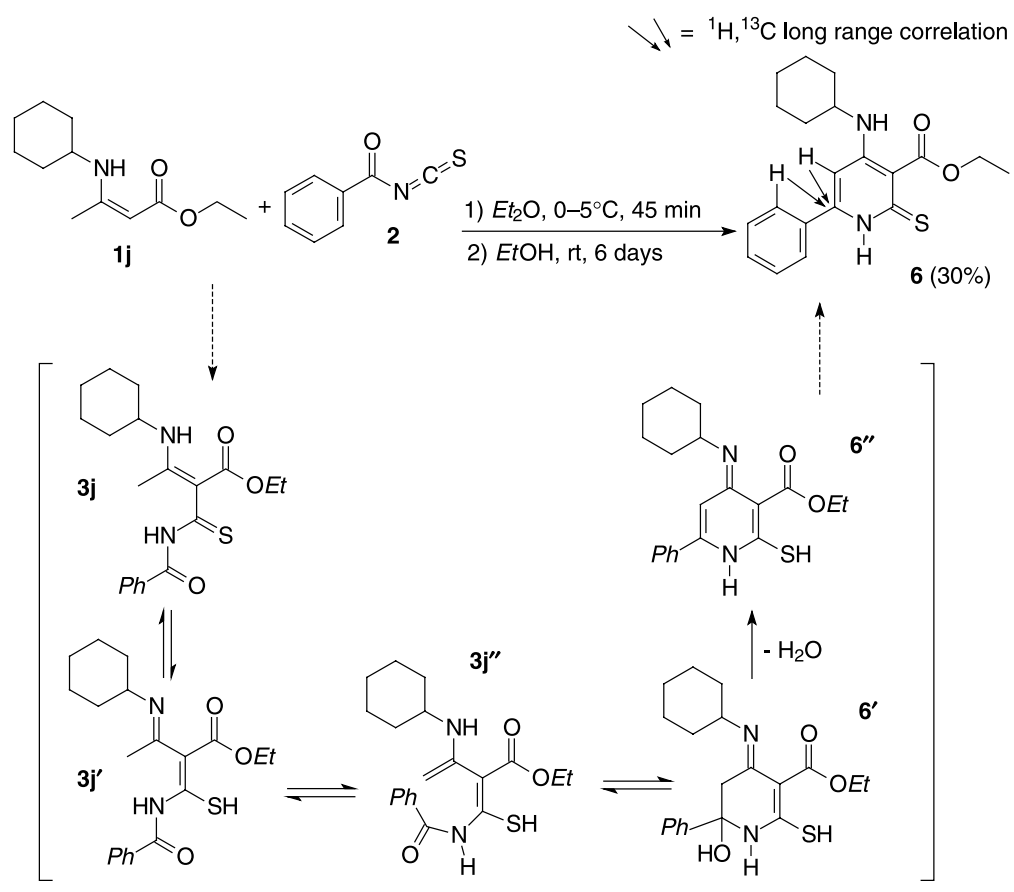

Scheme 3 
ORTEP representation of the solid state structure of $\mathbf{4 e}$ is shown in Fig. 3 as an example.

Sterically hindered alkyl substituents, like isopropyl and cyclohexyl groups, were not tolerated in the formal aza-[3+3] cycloaddition, being a limiting factor in the $\mathrm{N}$-alkyl 4-thioxopyrimidines synthesis. Although a complex mixture of products was formed with $N$-cyclohexyl substituted $\beta$-enamino ester $\mathbf{1 j}$, pyridin-2-thione 6 could be isolated and its structure and regiochemistry of cyclization was investigated by ${ }^{1} \mathrm{H},{ }^{13} \mathrm{C}$ long range correlation, as indicated in Scheme 3. Thus, the ortho hydrogens of the phenyl ring and the hydrogen at $\mathrm{C} 5$ of the pyridin-2-thione nucleus present a common correlation with the C-6 carbon near to the endocyclic nitrogen of $\mathbf{6}$, and this spectral feature is in accordance with the indicated structure. A mechanistic rationalization is also shown in Scheme 3, whereby formation of $\mathrm{C}$-adduct $\mathbf{3 j}$ is followed by a sequence of tautomeric equilibria that first result in $\mathbf{3} \mathbf{j}^{\prime}$ and by the involvement of the methyl group form transient enamine $\mathbf{3 j}$ ", which reacts with the benzoyl moiety to yield the heterocyclic core $\mathbf{6}^{\prime}$. After this, elimination of water affords 6" and proton migration results in pyridin2-thione 6. The steric hindrance of the cyclohexyl group obviously inhibits the intramolecular $\mathrm{N}$-acyla- tion step that is necessary to form the expected thioxopyrimidine. Moreover, formation of $\mathbf{6}$ involves the incorporation of a methyl group and the nucleophilic $\alpha$ carbon of enaminone $\mathbf{1 j}$ into the heterocyclic ring. To the best of our knowledge, there is only one previous example of pyridin-2-thione synthesis through an enaminone annulation [5f].

In the reaction of enaminones with phenyl isothiocyanate, it has been demonstrated that the obtained $\mathrm{C}$-adduct is a versatile intermediate for the synthesis of pyrazoles in good yields [9]. These results inspired us to try a similar reaction with the unstable intermediate 3 . We reasoned that this would be a good strategy to form complex heterocycles because intermediate $\mathbf{3}$ possesses an additional electrophilic carbonyl when compared with the analogous Cadduct [9]. Additionally, the second step of the aza-annulation here studied is a slow reaction (see Scheme 2 and Table 1), which suggests the possibility of trapping the $\mathrm{C}$-adduct $\mathbf{3}$ with a nitrogen nucleophile. Therefore, were reacted enaminones 1a and $\mathbf{1 b}$ with benzoyl isothiocyanate (2) and tentatively trapped intermediate $\mathbf{3}$ with diverse bisnucleophiles. Disappointingly, this reactions afforded complex mixtures. Probably, the additional electrophilic carbonyl center of $\mathbf{3}$ confers a great reactiv-

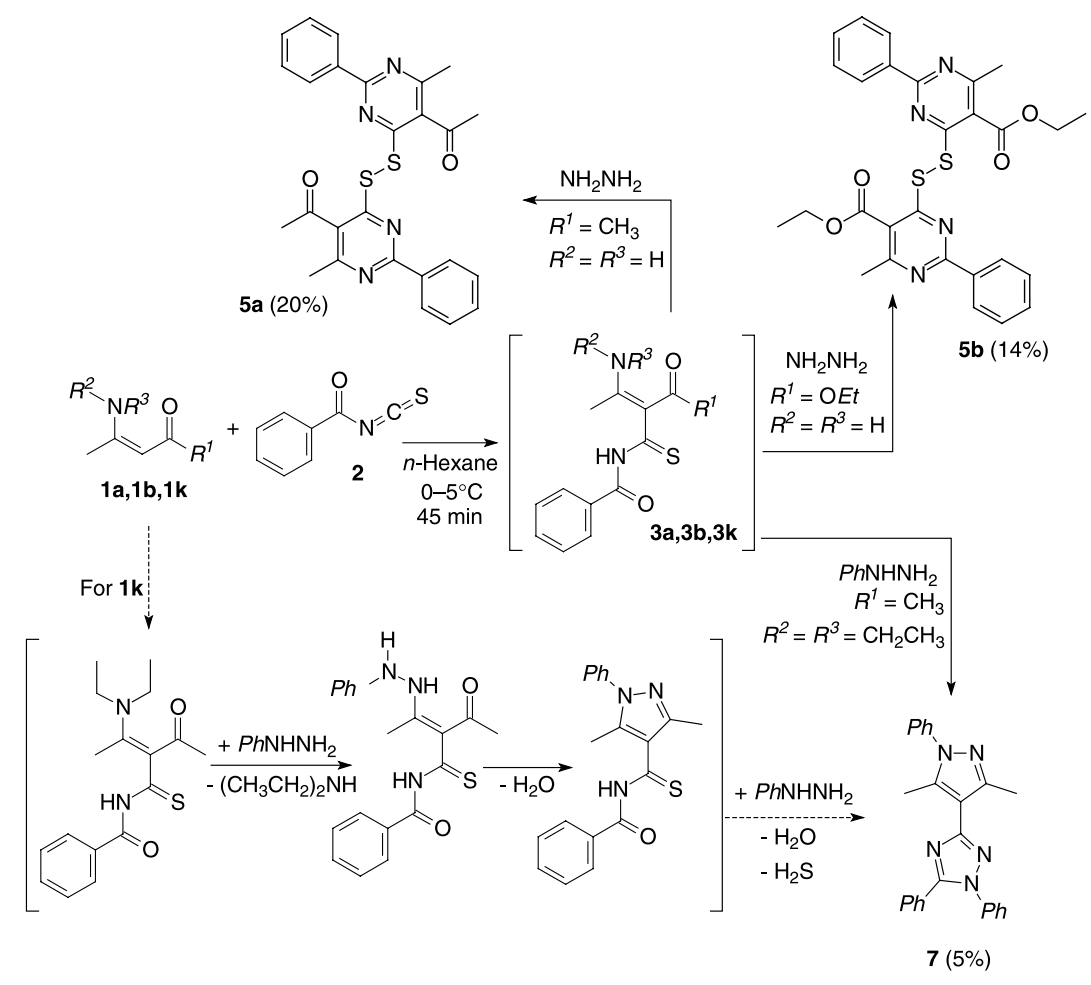

Scheme 4 


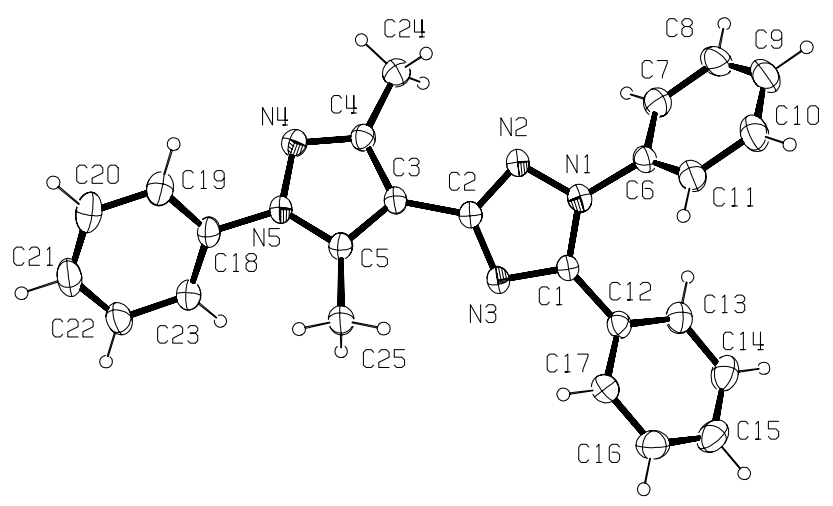

Fig. 4. ORTEP drawing of 7 with atom-numbering scheme; the displacement ellipsoids are drawn at $30 \%$ probability levels

ity to this intermediate under these conditions and no selective reaction occurred. When hydrazine was employed only disulfides $\mathbf{5 a}$ and $\mathbf{5 b}$ were isolated, Scheme 4. Meanwhile, the reaction of the phenylhydrazine and $\mathrm{C}$-adduct $\mathbf{3 k}$ from enaminone $\mathbf{1 k}$ provided 7, albeit in very low yield. Despite this finding, formation of heterocycle $\mathbf{7}$ is noteworthy because it combines a pyrazole linked to a $1,2,4$ triazole ring. Scheme 4 summarizes theses results and also shows a mechanistic proposal for the formation of 7, whose structure was unambiguously assigned by X-ray analysis, as shown in Fig. 4.

The thioxopyrimidines were individually tested for antibacterial activity against B. subtilis ATCC 6633, S. aureus ATCC 6638, M. luteus ATCC 10240, S. mutans ATCC 24175, Salmonella choleraesuis ATCC 14028, E. coli ATCC 94863, P. aeruginosa, C. albicans ATCC 18804, A. niger ATCC 16404, and $C$. cladosporioides IMI 178517 by broth microdilution method. For the purpose of antimicrobial evaluation, $4 \mathbf{e}$ and $\mathbf{4} \mathbf{i}$ were acetylated affording derivatives $\mathbf{4 j}$ and $\mathbf{4 k}$ in excellent yields, Scheme 2 . Whereas $\mathbf{4 g}, \mathbf{4 j}$, and $\mathbf{4 i}$ exhibited antimicrobial activity with $M I C$ values of $100 \mu \mathrm{g} / \mathrm{cm}^{3}$ for C. albicans, compounds $\mathbf{4 b}$ and $\mathbf{4 c}$ were active against $M$. luteus with $M I C$ values of 100 and $50 \mu \mathrm{g} / \mathrm{cm}^{3}$.

Additionally, thioxopyrimidines $4 \mathbf{c}, 4 \mathbf{d}, \mathbf{4 e}, \mathbf{4 h}$, and $4 \mathbf{i}$ were also evaluated in vitro against epimastigotes of Trypanosoma cruzi and their $I C_{50}$ values were determined, Table 1. All tested derivatives showed trypanocidal activity, albeit modest. This result suggests that the structural modification in the 4-thioxopyrimidine scaffold to improve the anti-Trypanosoma cruzi property deserves attention.
In conclusion, we developed a simple two-step onepot synthesis procedure for the formal aza- $[3+3]$ cycloaddition between $\mathrm{N}$-alkyl substituted enaminones and benzoyl isothiocyanate which afforded 4-thioxopyrimidines in good yields and under mild conditions. This work also suggests the potential of intermediate $\mathbf{3}$ in the formation of complex N-heterocycles. Efforts are underway to optimize yields and elucidate the mechanistic details of the reaction of intermediate $\mathbf{3}$ with bisnucleophiles and define the scope, limitations, and synthesis applications. This will be reported in due course.

\section{Experimental}

Melting points were determined on a Microquímica MQAPF 301 hot plate apparatus. Infrared spectra were recorded with $\mathrm{KBr}$ discs on a FT-IR BOMEM MB100 instrument. NMR spectra were obtained for ${ }^{1} \mathrm{H}$ at $300 \mathrm{MHz}$ and for ${ }^{13} \mathrm{C}$ at $75 \mathrm{MHz}$ using a Varian Gemini 300 spectrometer. Chemical shifts are reported in ppm units downfield from reference (internal $T M S$ ). Elemental analyses were performed on a 2400 CHN Perkin Elmer instrument. Their results agreed favourably with the calculated values. Enaminones $\mathbf{1 a}-\mathbf{1 k}$ were prepared according to known procedures [10]. The physical properties (mp, spectra) of known compounds $4 \mathbf{a}, \mathbf{4 b}, \mathbf{5 a}$ and $\mathbf{5 b}$ are in agreement with the literature [5a, 5c, 5h].

1-(4-Methyl-2-phenyl-6-thioxo-1,6-dihydro-5-pyrimidinyl)1-ethanone (4a, $\mathrm{C}_{13} \mathrm{H}_{12} \mathrm{~N}_{2} \mathrm{OS}$ )

To a solution of $1.0 \mathrm{mmol}$ enaminone $1 \mathrm{a}$ in $5 \mathrm{~cm}^{3}$ isopropyl ether was added dropwise a solution of $1.1 \mathrm{mmol}$ benzoyl isothiocyanate in $5 \mathrm{~cm}^{3}$ dry ethyl ether under ice-bath cooling and magnetic stirring. After $15 \mathrm{~min}$ the ice-bath was removed and the reaction mixture was left at room temperature for 5 days, while the progress of the reaction was monitored by TLC, after which time the solvent was evaporated. The residue was recrystallized from ethyl acetate/petroleum ether to give $30 \%$ 4a as yellow solid, mp $120.0-121.0^{\circ} \mathrm{C} .{ }^{1} \mathrm{H}$ NMR $\left(300 \mathrm{MHz}, \mathrm{CDCl}_{3}\right): \delta=2.66(3 \mathrm{H}, \mathrm{s}), 2.75(3 \mathrm{H}, \mathrm{s}), 7.32-7.43$ $(3 \mathrm{H}, \mathrm{m}), 8.25(2 \mathrm{H}, \mathrm{d}, J=6.9 \mathrm{~Hz}) \mathrm{ppm} ;{ }^{13} \mathrm{C} \mathrm{NMR}(75 \mathrm{MHz}$, $\left.\mathrm{CDCl}_{3}\right): \delta=23.84\left(\mathrm{CH}_{3}\right), 32.02\left(\mathrm{CH}_{3}\right), 128.63(\mathrm{CH}), 128.91$ $(\mathrm{CH}), 129.75(\mathrm{CH}), 131.65(\mathrm{C}), 136.51(\mathrm{C}), 162.83(\mathrm{C}), 163.59$ (C), 165.58 (C), 201.21 (C) ppm; IR (KBr): $\bar{\nu}=3309,1682$, $1537 \mathrm{~cm}^{-1}$.

General Synthesis Procedure for $4 \boldsymbol{b}, 5 a, 4 c-4 i$, and 6 To a solution of $1.0 \mathrm{mmol}$ enaminone $\mathbf{1 a}-\mathbf{1 j}$ in $5 \mathrm{~cm}^{3}$ dry ethyl ether was added dropwise a solution of $1.2 \mathrm{mmol}$ benzoyl isothiocyanate in $5 \mathrm{~cm}^{3}$ dry ethyl ether under ice-bath cooling and magnetic stirring. After $15 \mathrm{~min}$ the ice-bath was removed and the reaction mixture was left for $30 \mathrm{~min}$ at room temperature, after which time the solvent was evaporated. $10 \mathrm{~cm}^{3}$ ethyl alcohol were added and the solution was reacted at room temperature for the time indicated in each case (or in Table 1 for $\mathbf{4} \mathbf{c}-\mathbf{4 i}$ ), while the progress of the reaction was monitored 
by TLC. The solvent was evaporated and the crude residue was treated as indicated in each case.

Ethyl 4-methyl-2-phenyl-6-thioxo-1,6-dihydro-

5-pyrimidinecarboxylate $\left(4 \mathbf{b}, \mathrm{C}_{14} \mathrm{H}_{16} \mathrm{~N}_{2} \mathrm{O}_{3} \mathrm{~S}\right)$

Reaction time: 3 days. Recrystallized from ethyl acetate/ petroleum ether, mp $150.0-151.1^{\circ} \mathrm{C}$. ${ }^{1} \mathrm{H}$ NMR $(300 \mathrm{MHz}$, $\left.\mathrm{CDCl}_{3}+\left(\mathrm{CD}_{3}\right)_{2} \mathrm{CO}\right): \delta=1.42(3 \mathrm{H}, \mathrm{t}, J=6.9 \mathrm{~Hz}), 2.44(3 \mathrm{H}$, s), $4.46(2 \mathrm{H}, \mathrm{q}, J=6.9 \mathrm{~Hz}), 7.51-7.79(3 \mathrm{H}, \mathrm{m}), 8.10-8.14$ $(2 \mathrm{H}, \mathrm{m}) \mathrm{ppm} ;{ }^{13} \mathrm{C} \mathrm{NMR}\left(75 \mathrm{MHz}, \mathrm{CDCl}_{3}+\left(\mathrm{CD}_{3}\right)_{2} \mathrm{CO}\right)$ : $\delta=14.09\left(\mathrm{CH}_{3}\right), 22.40\left(\mathrm{CH}_{3}\right), 61.89\left(\mathrm{CH}_{2}\right), 128.30(\mathrm{CH})$, $128.44(\mathrm{C}), 128.95(\mathrm{CH}), 131.33(\mathrm{C}), 132.55(\mathrm{C}), 156.78(\mathrm{C})$, $158.41(\mathrm{C}), 166.44(\mathrm{C}), 182.28(\mathrm{C}) \mathrm{ppm}$.

\section{1-[4-(5-Acetyl-6-methyl-2-phenyl-4-}

pyrimidinyldisulfanyl)-6-methyl-2-phenyl-5-

pyrimidinyl]-1-ethanone $\left(\mathbf{5 a}, \mathrm{C}_{26} \mathrm{H}_{22} \mathrm{~N}_{4} \mathrm{O}_{2} \mathrm{~S}_{2}\right)$

Reaction time: 6 days. Recrystallized from ethyl ether/ petroleum ether, mp 189.0-190.1 ${ }^{\circ} \mathrm{C}$. ${ }^{1} \mathrm{H}$ NMR $(300 \mathrm{MHz}$, $\left.\mathrm{CDCl}_{3}\right): \delta=2.35(3 \mathrm{H}, \mathrm{s}), 2.65(3 \mathrm{H}, \mathrm{s}), 7.54-7.63(3 \mathrm{H}, \mathrm{m})$, $8.01(2 \mathrm{H}, \mathrm{d}, J=7.5 \mathrm{~Hz}) \mathrm{ppm} ;{ }^{13} \mathrm{C} \mathrm{NMR}\left(75 \mathrm{MHz}, \mathrm{CDCl}_{3}\right)$ : $\delta=22.25\left(\mathrm{CH}_{3}\right), 30.62\left(\mathrm{CH}_{3}\right), 127.39(\mathrm{CH}), 129.45(\mathrm{CH})$, $130.52(\mathrm{C}), 133.05(\mathrm{CH}), 136.52(\mathrm{C}), 155.51(\mathrm{C}), 158.15(\mathrm{C})$, 179.28 (C), 201.95 (C) ppm; IR (KBr): $\bar{\nu}=1694,1558,1218$, $1199 \mathrm{~cm}^{-1}$.

1-(1-Benzyl-6-methyl-2-phenyl-4-thioxo-1,4-dihydro5-pyrimidinyl)-1-ethanone $\left(4 \mathrm{c}, \mathrm{C}_{20} \mathrm{H}_{18} \mathrm{~N}_{2} \mathrm{OS}\right)$

Trituration with $n$-hexane, mp $163.8-164.2^{\circ} \mathrm{C} .{ }^{1} \mathrm{H}$ NMR $\left(300 \mathrm{MHz}, \mathrm{CDCl}_{3}\right): \delta=2.14(3 \mathrm{H}, \mathrm{s}), 2.64(3 \mathrm{H}, \mathrm{s}), 5.20(2 \mathrm{H}$, s), $6.97(2 \mathrm{H}, \mathrm{d}, J=6.9 \mathrm{~Hz}), 7.53(8 \mathrm{H}, \mathrm{m}) \mathrm{ppm} ;{ }^{13} \mathrm{C} \mathrm{NMR}$ $\left(75 \mathrm{MHz}, \mathrm{CDCl}_{3}\right): \delta=16.67\left(\mathrm{CH}_{3}\right), 30.67\left(\mathrm{CH}_{3}\right), 53.87(\mathrm{CH})$, $125.50(\mathrm{CH}), 128.51(\mathrm{CH}), 128.82(\mathrm{CH}), 128.98(\mathrm{CH}), 129.82$ (CH), $131.13(\mathrm{CH}), 134.46(\mathrm{C}), 137.99(\mathrm{C}), 142.47(\mathrm{C}), 157.06$ (C), 194.06 (C), 201.43 (C) ppm; IR (KBr): $\bar{\nu}=1708,1596$, $1289,1127 \mathrm{~cm}^{-1}$.

\section{1-(1-Butyl-6-methyl-2-phenyl-4-thioxo-1,4-dihydro-}

5-pyrimidinyl)-1-ethanone $\left(4 \mathrm{~d}, \mathrm{C}_{17} \mathrm{H}_{20} \mathrm{~N}_{2} \mathrm{OS}\right)$

Recrystallized from $\mathrm{CH}_{2} \mathrm{Cl}_{2}$ /petroleum ether, mp 222.3223. $2^{\circ} \mathrm{C} .{ }^{1} \mathrm{H}$ NMR $\left(300 \mathrm{MHz}, \mathrm{CDCl}_{3}\right): \delta=0.72(3 \mathrm{H}, \mathrm{t}$, $J=7.5 \mathrm{~Hz}), 1.10(2 \mathrm{H}$, sextet, $J=7.5 \mathrm{~Hz}), 1.50(2 \mathrm{H}$, quintet, $J=7.5 \mathrm{~Hz}$ ), 2.29 (3H, s), 2.63 (3H, s), 3.91 (2H, m), 7.49$7.53(5 \mathrm{H}, \mathrm{m}) \mathrm{ppm} ;{ }^{13} \mathrm{C} \mathrm{NMR}\left(75 \mathrm{MHz}, \mathrm{CDCl}_{3}\right): \delta=13.11$ $\left(\mathrm{CH}_{3}\right), 16.15\left(\mathrm{CH}_{3}\right), 19.18\left(\mathrm{CH}_{3}\right), 30.34\left(\mathrm{CH}_{2}\right), 32.00\left(\mathrm{CH}_{2}\right)$, $49.82\left(\mathrm{CH}_{2}\right), 128.35(\mathrm{CH}), 128.78(\mathrm{CH}), 130.74(\mathrm{CH}), 133.32$ (C), 137.68 (C), 141.53 (C), 156.35 (C), 193.08 (C), 201.36 (C) ppm; IR (KBr): $\bar{\nu}=1699,1590,1287 \mathrm{~cm}^{-1}$.

\section{1-[1-(2-Hydroxyethyl)-6-methyl-2-phenyl-4-thioxo-1,4-} dihydro-5-pyrimidinyl]-1-ethanone $\left(4 \mathrm{e}, \mathrm{C}_{15} \mathrm{H}_{16} \mathrm{~N}_{2} \mathrm{O}_{2} \mathrm{~S}\right)$ Recrystallized from $\mathrm{CH}_{2} \mathrm{Cl}_{2}$ /petroleum ether, mp 235.7$236.6^{\circ} \mathrm{C} .{ }^{1} \mathrm{H}$ NMR $\left(300 \mathrm{MHz}, D M S O-\mathrm{d}_{6}\right): \delta=2.29(3 \mathrm{H}, \mathrm{s})$, $2.52(3 \mathrm{H}, \mathrm{s}), 3.42(2 \mathrm{H}, \mathrm{t}, J=5.4 \mathrm{~Hz}), 4.01(2 \mathrm{H}, \mathrm{t}, J=6.0 \mathrm{~Hz})$,

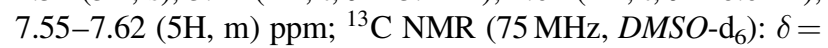
$17.37\left(\mathrm{CH}_{3}\right), 31.13\left(\mathrm{CH}_{3}\right), 52.38\left(\mathrm{CH}_{2}\right), 59.70\left(\mathrm{CH}_{2}\right), 129.13$ (CH), $129.21(\mathrm{CH}), 130.81(\mathrm{CH}), 135.06(\mathrm{C}), 137.29(\mathrm{C})$,
144.99 (C), 157.29 (C), 192.40 (C), 201.79 (C) ppm; IR (KBr): $\bar{\nu}=3327,1703,1593,1514,1479,1288,1190,1055 \mathrm{~cm}^{-1}$.

1-[1-(2-Methoxyethyl)-6-methyl-2-phenyl-4-thioxo-1,4dihydro-5-pyrimidinyl]-1-ethanone (4f, $\left.\mathrm{C}_{16} \mathrm{H}_{18} \mathrm{~N}_{2} \mathrm{O}_{2} \mathrm{~S}\right)$

Recrystallized from $\mathrm{CH}_{2} \mathrm{Cl}_{2}$ /petroleum ether, mp 162.4164.0 ${ }^{\circ} \mathrm{C} .{ }^{1} \mathrm{H}$ NMR $\left(300 \mathrm{MHz}, \mathrm{CDCl}_{3}\right): \delta=2.32(3 \mathrm{H}, \mathrm{s})$, $2.64(3 \mathrm{H}, \mathrm{s}), 3.33(2 \mathrm{H}, \mathrm{t}, J=5.1 \mathrm{~Hz}), 4.20(2 \mathrm{H}, \mathrm{t}, J=5.1 \mathrm{~Hz})$, 7.48-7.51 (5H, m) ppm; ${ }^{13} \mathrm{C}$ NMR $\left(75 \mathrm{MHz}, \mathrm{CDCl}_{3}\right)$ : $\delta=17.14\left(\mathrm{CH}_{3}\right), 30.72\left(\mathrm{CH}_{3}\right), 49.42\left(\mathrm{CH}_{2}\right), 59.49\left(\mathrm{CH}_{3}\right)$, $70.78\left(\mathrm{CH}_{2}\right), 128.73(\mathrm{CH}), 129.08(\mathrm{CH}), 130.84(\mathrm{CH})$, 137.36 (C), 142.90 (C), 156.56 (C), 164.10 (C), 201.83 (C) ppm; IR $(\mathrm{KBr}): \bar{\nu}=1702,1595 \mathrm{~cm}^{-1}$.

Ethyl 1-benzyl-6-methyl-2-phenyl-4-thioxo-1,4-dihydro-

5-pyrimidinecarboxylate $\left(4 \mathrm{~g}, \mathrm{C}_{21} \mathrm{H}_{20} \mathrm{~N}_{2} \mathrm{O}_{2} \mathrm{~S}\right)$

Recrystallized from ethyl acetate/petroleum ether, mp 119.1$120.1^{\circ} \mathrm{C} .{ }^{1} \mathrm{H}$ NMR $\left(300 \mathrm{MHz}, \mathrm{CDCl}_{3}\right): \delta=1.39(3 \mathrm{H}, \mathrm{t}$, $J=7.2 \mathrm{~Hz}), 2.20(3 \mathrm{H}, \mathrm{s}), 4.41(2 \mathrm{H}, \mathrm{q}, J=7.2 \mathrm{~Hz}), 5.17(2 \mathrm{H}$, s), $6.97(2 \mathrm{H}, \mathrm{d}, J=6.3 \mathrm{~Hz}) 7.32-7.50(8 \mathrm{H}, \mathrm{m}) \mathrm{ppm} ;{ }^{13} \mathrm{C} \mathrm{NMR}$ $\left(75 \mathrm{MHz}, \mathrm{CDCl}_{3}\right): \delta=13.99\left(\mathrm{CH}_{3}\right), 17.19\left(\mathrm{CH}_{3}\right), 53.63\left(\mathrm{CH}_{2}\right)$, $62.24\left(\mathrm{CH}_{2}\right), 125.20(\mathrm{CH}), 125.31(\mathrm{CH}), 128.18(\mathrm{CH}), 128.53$ $(\mathrm{CH}), 128.69(\mathrm{CH}), 129.56(\mathrm{CH}), 130.78(\mathrm{C}), 131.93(\mathrm{C}), 133.34$ (C), 134.27 (C), $137.99(\mathrm{C}), 143.28(\mathrm{C}), 156.69(\mathrm{C}), 166.00(\mathrm{C})$, 193.96 (C) ppm; IR (KBr): $\bar{\nu}=1730,1599,1238 \mathrm{~cm}^{-1}$.

Ethyl 1-butyl-6-methyl-2-phenyl-4-thioxo-1,4-dihydro5-pyrimidinecarboxylate $\left(4 \mathrm{~h}, \mathrm{C}_{18} \mathrm{H}_{22} \mathrm{~N}_{2} \mathrm{O}_{2} \mathrm{~S}\right)$

Recrystallized from ethanol, $\mathrm{mp} 174.6-175.6^{\circ} \mathrm{C} .{ }^{1} \mathrm{H}$ NMR $\left(300 \mathrm{MHz}, \mathrm{CDCl}_{3}\right): \delta=0.72(3 \mathrm{H}, \mathrm{t}, J=7.2 \mathrm{~Hz}), 1.11(2 \mathrm{H}$, sextet, $J=7.2 \mathrm{~Hz}) 1.41(3 \mathrm{H}, \mathrm{t}, J=7.2 \mathrm{~Hz}), 1.49(2 \mathrm{H}$, quintet, $J=7.8 \mathrm{~Hz}), 2.34(3 \mathrm{H}, \mathrm{s}), 3.90(2 \mathrm{H}, \mathrm{d}, J=7.8 \mathrm{~Hz}), 4.32(2 \mathrm{H}, \mathrm{q}$, $J=7.2 \mathrm{~Hz}), 7.48-7.50(5 \mathrm{H}, \mathrm{m}) \mathrm{ppm} ;{ }^{13} \mathrm{C} \mathrm{NMR}(75 \mathrm{MHz}$, $\left.\mathrm{CDCl}_{3}\right): \delta=13.34\left(\mathrm{CH}_{3}\right), 14.22\left(\mathrm{CH}_{3}\right), 17.11\left(\mathrm{CH}_{3}\right), 19.72$ $\left(\mathrm{CH}_{2}\right), 32.25\left(\mathrm{CH}_{2}\right), 50.03\left(\mathrm{CH}_{2}\right), 62.46\left(\mathrm{CH}_{2}\right), 128.53(\mathrm{CH})$, $129.00(\mathrm{CH}), 130.90(\mathrm{CH}), 132.16(\mathrm{C}), 133.60(\mathrm{C}), 142.55$ (C), 156.45 (C), 166.26 (C), 193.34 (C) ppm; IR (KBr): $\bar{\nu}=3052,1721,1603 \mathrm{~cm}^{-1}$.

Ethyl 1-(2-hydroxyethyl)-6-methyl-2-phenyl-4-thioxo1,4-dihydro-5-pyrimidinecarboxylate $\left(4 \mathrm{i}, \mathrm{C}_{16} \mathrm{H}_{18} \mathrm{~N}_{2} \mathrm{O}_{3} \mathrm{~S}\right)$ Recrystallized from ethanol, ${ }^{1} \mathrm{H}$ NMR $\left(300 \mathrm{MHz}, D M S O-\mathrm{d}_{6}\right)$ : $\delta=1.29(3 \mathrm{H}, \mathrm{t}, J=6.9 \mathrm{~Hz}), 2.35(3 \mathrm{H}, \mathrm{s}), 3.38(1 \mathrm{H}, \mathrm{br}) 3.40$ $(2 \mathrm{H}, \mathrm{t}, J=5.4 \mathrm{~Hz}), 4.04(2 \mathrm{H}, \mathrm{t}, J=5.4 \mathrm{~Hz}), 4.26(2 \mathrm{H}, \mathrm{q}$, $J=6.9 \mathrm{~Hz}), 7.53-7.61(5 \mathrm{H}, \mathrm{m}) \mathrm{ppm} ;{ }^{13} \mathrm{C} \mathrm{NMR}(75 \mathrm{MHz}$, DMSO-d $\left.{ }_{6}\right): \delta=13.69\left(\mathrm{CH}_{3}\right), 17.27\left(\mathrm{CH}_{3}\right), 51.59\left(\mathrm{CH}_{2}\right), 58.86$ $\left(\mathrm{CH}_{2}\right), 61.15\left(\mathrm{CH}_{2}\right), 128.25(\mathrm{CH}), 128.38(\mathrm{CH}), 129.96(\mathrm{CH})$, 130.53 (C), 134.53 (C), 145.29 (C), 156.36 (C), 165.59 (C), 191.85 (C) ppm; IR (KBr): $\bar{\nu}=3408,1727,1606 \mathrm{~cm}^{-1}$.

Ethyl 4-cyclohexylamino-6-phenyl-2-thioxonicotinate

(6, $\mathrm{C}_{20} \mathrm{H}_{24} \mathrm{~N}_{2} \mathrm{O}_{2} \mathrm{~S}$ )

Recrystallized from ethanol, ${ }^{1} \mathrm{H}$ NMR $\left(300 \mathrm{MHz}, \mathrm{CDCl}_{3}\right)$ : $\delta=1.40(3 \mathrm{H}, \mathrm{t}, J=7.2 \mathrm{~Hz}), 1.30-1.88(10 \mathrm{H}, \mathrm{m}), 3.56(1 \mathrm{H}$, $\mathrm{m}), 4.36(2 \mathrm{H}, \mathrm{q}, J=7.2 \mathrm{~Hz}), 6.41(1 \mathrm{H}, \mathrm{s}), 7.46-7.52(3 \mathrm{H}, \mathrm{m})$, $7.85(2 \mathrm{H}, \mathrm{d}, J=5.7 \mathrm{~Hz}), 10.16(1 \mathrm{H}, \mathrm{br}) \mathrm{ppm} ;{ }^{13} \mathrm{C} \mathrm{NMR}$ $\left(75 \mathrm{MHz}, D M S O-\mathrm{d}_{6}\right): \delta=14.43\left(\mathrm{CH}_{3}\right), 24.20\left(\mathrm{CH}_{2}\right), 25.24$ 
$\left(\mathrm{CH}_{2}\right), 33.05\left(\mathrm{CH}_{2}\right), 51.78(\mathrm{CH}), 60.50(\mathrm{CH}), 91.79(\mathrm{CH})$, 126.27 (C), $128.84(\mathrm{C}), 131.36(\mathrm{C}), 131.47(\mathrm{CH}), 159.71(\mathrm{C})$, $160.41(\mathrm{C}), 162.04$ (C), 170.12 (C) ppm.

Ethyl 4-(5-ethyloxycarbonyl-6-methyl-2-phenyl4-pyrimidinyldisulfanyl)-6-methyl-2-phenyl5-pyrimidinecarboxylate $\left(\mathbf{5 b}, \mathrm{C}_{28} \mathrm{H}_{26} \mathrm{~N}_{4} \mathrm{O}_{4} \mathrm{~S}_{2}\right)$

To a solution of $1.0 \mathrm{mmol}$ enaminone $1 \mathrm{a}$ in $5 \mathrm{~cm}^{3}$ dry ethyl ether was added dropwise a solution of $1.2 \mathrm{mmol}$ benzoyl isothiocyanate in $5 \mathrm{~cm}^{3}$ dry ethyl ether under ice-bath cooling and magnetic stirring. After $15 \mathrm{~min}$ the ice-bath was removed and the reaction mixture was left for $30 \mathrm{~min}$ at room temperature, after which time the solvent was evaporated. $10 \mathrm{~cm}^{3}$ ethyl alcohol were added and the solution was reacted at reflux, while the progress of the reaction was monitored by TLC. After 1 day, the solvent was evaporated and the residue was recrystallized from ethyl acetate/petroleum ether to give $75 \%$ 5b, mp $129.7-130.4^{\circ} \mathrm{C} .{ }^{1} \mathrm{H}$ NMR $\left(300 \mathrm{MHz}, \mathrm{CDCl}_{3}\right)$ : $\delta=1.42(3 \mathrm{H}, \mathrm{t}, J=7.0 \mathrm{~Hz}), 2.44(3 \mathrm{H}, \mathrm{s}), 4.45(2 \mathrm{H}, \mathrm{q}, J=$ $7.0 \mathrm{~Hz}), \quad 7.51-7.63(3 \mathrm{H}, \mathrm{m}), 8.05-8.08(2 \mathrm{H}, \mathrm{m}) \mathrm{ppm}$; ${ }^{13} \mathrm{C}$ NMR $\left(75 \mathrm{MHz}, \mathrm{CDCl}_{3}\right): \delta=14.03\left(\mathrm{CH}_{3}\right), 22.73\left(\mathrm{CH}_{3}\right)$, $62.05\left(\mathrm{CH}_{2}\right), 127.67(\mathrm{CH}), 129.21(\mathrm{CH}), 131.20(\mathrm{C}), 132.76$ (C), 156.61 (C), 159.99 (C), 166.07 (C), 178.51 (C) ppm; IR $(\mathrm{KBr}): \bar{\nu}=1731,1581,1567,1233,1086 \mathrm{~cm}^{-1}$.

\section{Synthesis of the Intermediate Benzamides 3}

To a solution of $1.0 \mathrm{mmol}$ enaminone $\mathbf{1 a}-\mathbf{1 j}$ in $5 \mathrm{~cm}^{3} n$-hexane was added dropwise a solution of $1.1 \mathrm{mmol}$ benzoyl isothiocyanate in $5 \mathrm{~cm}^{3} n$-hexane under ice-bath cooling and magnetic stirring. After $15 \mathrm{~min}$ the ice-bath was removed and the reaction mixture was left for $30 \mathrm{~min}$ at room temperature, after which time the solvent was evaporated. The residue was recrystallized from ethyl acetate/petroleum ether.

\section{$N$-[(E)-2-Acetyl-3-amino-1-thioxo-2-butenyl]benzamide}

(3a, $\mathrm{C}_{13} \mathrm{H}_{14} \mathrm{~N}_{2} \mathrm{O}_{2} \mathrm{~S}$ )

Yield 75\%, mp 130.0-131.0 ${ }^{\circ}$; ${ }^{1} \mathrm{H}$ NMR $\left(300 \mathrm{MHz}, \mathrm{CDCl}_{3}\right)$ : $\delta=2.16(3 \mathrm{H}, \mathrm{s}), 2.21(3 \mathrm{H}, \mathrm{s}), 7.53(2 \mathrm{H}, \mathrm{m}), 7.63(1 \mathrm{H}, \mathrm{m}), 7.91$ $(2 \mathrm{H}, \mathrm{m}) \mathrm{ppm} ;{ }^{13} \mathrm{C} \mathrm{NMR}\left(75 \mathrm{MHz}, \mathrm{CDCl}_{3}\right): \delta=22.46\left(\mathrm{CH}_{3}\right)$, $28.12\left(\mathrm{CH}_{3}\right), 114.52(\mathrm{C}), 127.88(\mathrm{CH}), 129.20(\mathrm{CH}), 132.34$ (C), 133.55 (CH), 160.82 (C), 162.31 (C), 193.01 (C), 207.12 (C) ppm.

\section{Acetylation of 4-Thioxopyrimidines $\mathbf{4 e}$ and $\mathbf{4 i}$}

To a solution of $1.0 \mathrm{mmol} \mathbf{4 e}, 4 \mathbf{i}$ in $10 \mathrm{~cm}^{3} D M F$ were added 5 drops of pyridine and $10 \mathrm{~cm}^{3}$ acetic anhydride. After $30 \mathrm{~min}$, $30 \mathrm{~cm}^{3} \mathrm{CH}_{2} \mathrm{Cl}_{2}$ were added and the mixture was extracted with brine $\left(5 \times 30 \mathrm{~cm}^{3}\right)$. The organic phase was dried over $\mathrm{MgSO}_{4}$, filtered, and the solvent was evaporated, affording pure $\mathbf{4 j}$ and $\mathbf{4 k}$.

2-(5-Acetyl-6-methyl-2-phenyl-4-thioxo-1,4-dihydro1-pyrimidinyl)ethyl acetate $\left(\mathbf{4 j}, \mathrm{C}_{17} \mathrm{H}_{18} \mathrm{~N}_{2} \mathrm{O}_{3} \mathrm{~S}\right)$

Yield 90\%, yellow solid, mp $207.0-207.8^{\circ} \mathrm{C} ;{ }^{1} \mathrm{H}$ NMR $\left(300 \mathrm{MHz}, \mathrm{CDCl}_{3}\right): \delta=2.00(3 \mathrm{H}, \mathrm{s}), 2.33(3 \mathrm{H}, \mathrm{s}), 2.63(3 \mathrm{H}$, $\mathrm{s}), 4.04(2 \mathrm{H}, \mathrm{t}, J=5.7 \mathrm{~Hz}), 4.31(2 \mathrm{H}, \mathrm{t}, J=5.7 \mathrm{~Hz}), 7.50-7.59$ (5H, m) ppm; $\left.{ }^{13} \mathrm{C} \mathrm{NMR} \mathrm{(75} \mathrm{MHz,} \mathrm{CDCl}_{3}\right): \delta=17.15\left(\mathrm{CH}_{3}\right)$,
$21.02\left(\mathrm{CH}_{3}\right), 30.70\left(\mathrm{CH}_{3}\right), 48.42\left(\mathrm{CH}_{2}\right), 61.82\left(\mathrm{CH}_{2}\right), 129.11$ $(\mathrm{CH}), 129.47(\mathrm{CH}), 161.59(\mathrm{CH}), 133.27(\mathrm{C}), 138.00(\mathrm{C})$, 142.14 (C), 156.85 (C), 170.49 (C), 193.66 (C), 201.59 (C) ppm; IR (KBr): $\bar{\nu}=1741,1697 \mathrm{~cm}^{-1}$.

\section{2-(5-Ethyloxycarbonyl-6-methyl-2-phenyl-4-thioxo-1,4-} dihydro-1-pyrimidinyl)ethyl acetate $\left(4 \mathbf{k}, \mathrm{C}_{18} \mathrm{H}_{20} \mathrm{~N}_{2} \mathrm{O}_{4} \mathrm{~S}\right)$ Yield $85 \% \mathrm{mp} 190.2-192.0^{\circ} \mathrm{C} ;{ }^{1} \mathrm{H} \mathrm{NMR}\left(300 \mathrm{MHz}, \mathrm{CDCl}_{3}\right)$ : $\delta=1.40(3 \mathrm{H}, \mathrm{t}, J=7.2 \mathrm{~Hz}), 1.99(3 \mathrm{H}, \mathrm{s}), 2.37(3 \mathrm{H}, \mathrm{s}), 4.02(2 \mathrm{H}$, $\mathrm{t}, J=5.7 \mathrm{~Hz}), 4.27(2 \mathrm{H}, \mathrm{t}, J=5.7 \mathrm{~Hz}), 4.43(2 \mathrm{H}, \mathrm{q}, J=7.2 \mathrm{~Hz})$, $7.50-7.59(5 \mathrm{H}, \mathrm{m}) \mathrm{ppm}$; IR $(\mathrm{KBr}): \bar{\nu}=1744,1729 \mathrm{~cm}^{-1}$.

\section{3-(3,5-Dimethyl-1-phenyl-1H-4-pyrazolyl)-1,5-diphenyl-}

1H-1,2,4-triazole $\left(7, \mathrm{C}_{25} \mathrm{H}_{21} \mathrm{~N}_{5}\right)$

To a solution of $788.7 \mathrm{mg}(5.1 \mathrm{mmol})$ enaminone $1 \mathrm{k}$ in $15 \mathrm{~cm}^{3}$ $n$-hexane were added $849.8 \mathrm{mg}(5.2 \mathrm{mmol})$ benzoyl isothiocyanate. After $30 \mathrm{~min}$ at room temperature the solvent was evaporated and $10 \mathrm{~cm}^{3}$ ethanol and $1.0 \mathrm{~cm}^{3}(10.2 \mathrm{mmol})$ phenylhydrazine were added. After $91 \mathrm{~h}$ the solvent was evaporated and the residue was recrystallized from ethyl alcohol/ petroleum ether to give $5 \% 7, \mathrm{mp} 188.2-189.0^{\circ} \mathrm{C}$. ${ }^{1} \mathrm{H}$ NMR $\left(300 \mathrm{MHz}, \mathrm{CDCl}_{3}\right): \delta=2.69\left(6 \mathrm{H}, \mathrm{s}, 2 \mathrm{CH}_{3}\right), 7.34-7.59(15 \mathrm{H}$, m) ppm; ${ }^{13} \mathrm{C} \mathrm{NMR}\left(75 \mathrm{MHz}, \mathrm{CDCl}_{3}\right): \delta=12.79\left(\mathrm{CH}_{3}\right), 14.19$ $\left(\mathrm{CH}_{3}\right), 110.94(\mathrm{C}), 125.56(\mathrm{CH}), 125.61(\mathrm{CH}), 127.92(\mathrm{CH})$, $128.53(\mathrm{C}), 128.75(\mathrm{CH}), 128.78(\mathrm{CH}), 129.23(\mathrm{CH}), 129.29$ $(\mathrm{CH}), 129.52(\mathrm{CH}), 130.09(\mathrm{C}), 138.73(\mathrm{C}), 139.72(\mathrm{C})$, 139.89 (C), 149.14 (C), 153.86 (C), 158.40 (C) ppm.

\section{Antibacterial and Antifungal Assay. Determination of Minimal Inhibitory Concentration (MIC)}

Values are means of three experiments. The bacteria cultures used were grown for $24 \mathrm{~h}$ at $35^{\circ} \mathrm{C}$ on nutrient agar. The fungi and yeasts were cultivated for $72 \mathrm{~h}$ at $26^{\circ} \mathrm{C}$ on malt extract agar and yeast malt agar. The inocula for the assays were prepared by cell suspensions according to McFarland scale 0.5 , except of filamentous fungi for which a modified method was used [11]. Broth microdilution method was carried out to determine the $M I C$ of the compounds against the microrganisms in sterile 96-well microplates. The 20\% DMSO aqueous stock solutions of the compounds were transferred into the first well from which serial dilutions were performed so that concentrations ranged from 100 to $0.78 \mu \mathrm{g} / \mathrm{cm}^{3}$. Chloramphenicol and olamine ciclopirox were used as the reference drugs against bacteria and fungi. Aqueous DMSO (20\%) was used as negative control. The inoculum was added to all wells and the plates were incubated under appropriate conditions. After incubation, microrganisms' growth was observed by the presence of turbidity on the well. MIC was defined as the lowest concentration of the substances that inhibited visible growth.

\section{Anti-Trypanosoma cruzi Assay}

Parasites epimastigotes of Trypanosoma cruzi Y-strain were cultivated at $28^{\circ} \mathrm{C}$ in plastic flasks containing $5 \mathrm{~cm}^{3}$ liver infusion trypticase medium inoculated with $5 \times 10^{6}$ cells $/ \mathrm{cm}^{3}$ and supplemented with $10 \%$ fetal calf serum. Cells from the mid$\log$ phase were harvested by centrifugation at $2.500 \mathrm{rpm}$ and fixed in formaldehyde and axenic prolifareation was assessed by counting in Neubauer chambers under light microscopy. 
Parasite's growth in the absence or presence of increasing concentrations of the different drugs was assessed by the absorbance determined at $610 \mathrm{~nm}$. The data are representative of a minimum of three independent experiments performed in triplicate, which yielded analogous results. Significant differences in control relation $\left({ }^{*} P<0.05\right.$, ${ }^{* *} P<0.01$ and $\left.{ }^{* *} P<0.001\right)$ were statistically analyzed using ANOVA.

\section{Crystallographic Data Collection and Structure}

\section{Determination of Compounds $\mathbf{4 b}, \mathbf{5 b}$, and 7}

Single crystals X-ray diffraction data were collected at room temperature using a Nonius CAD-4 diffratometer [12] with CuKa radiation $(\lambda=1.54180 \AA)$. The structures were solved by direct methods and refined anisotropically with full-matrix least-squares on $F^{2}$ using SHELXL97 [13]. The hydrogen atoms were placed at calculated positions, except those involved in H-bonds and weak interactions found on difference maps, and refined with riding constraints. The crystallographic data were deposited at the Cambridge Crystallographic Data Center under the numbers $C C D C$ 601662, 601657, and 601658. Copies of the data can be obtained, free of charge via www.ccdc.cam.ac.uk/conts/retrieving.html (or from the Cambrigde Crystallographic Data Centre, CCDC, 12 Union Road, Cambridge, CB2 1EZ, UK (fax +44 1223 336033, or e-mail: deposit@ccdc.cam.ac.uk).

\section{Acknowledgements}

The authors gratefully acknowledge the financial support of Conselho Nacional de Desenvolvimento Científico e Tecnológico - $C N P q$ and Fundação de Amparo à Pesquisa do Estado da Bahia - FAPESB. We also thank FEPESB for a fellowship to G.A.N.C. and $C N P q$ for scholarships to R.M.B. and P.O.S. (PIBIC-UFBA-CNPq), and for research fellowships to I.V. and S.C.

\section{References}

[1] a) Cocco MT, Congiu C, Onnis V, Piras R (2001) Farmaco 56: 741; b) Cocco MT, Congiu C, Onnis V (1995) Farmaco 50: 73

[2] For representative papers see: a) Aggarwal V, Ila H, Junjappa H (1982) Synthesis, 65; b) Carney RWJ, Wojtkunski J, deStevens G (1964) J Org Chem 29: 2887
[3] a) Hsung RP, Wei L-L, Sklenicka HM, Douglas CJ, McLaughlin MJ, Mulder JA, Yao LJ (1999) Org Lett 1: 509; b) Hickmott PW, Sheppard G (1971) J Chem Soc C 2112; c) Palvannan K, Stille JR (1992) J Org Chem 57: 5319; For reviews see: d) Harrity JPA, Provoost O (2005) Org Biomol Chem 3: 1349; e) Hsung RP, Kurdyumov AV, Sydorenko N (2005) Eur J Org Chem, 23

[4] For reviews see: a) Ferrar HMC, Pereira FLC (2004) Quim Nova 27: 89; b) Kascheres C (2003) J Braz Chem Soc 14: 945; c) Negri G, Kascheres C, Kascheres AJ (2004) J Heterocyclic Chem 41: 461

[5] a) Goerdeler J, Pohland WH (1963) Chem Ber 96: 526; b) Goerdeler J, Gnad J (1965) Chem Ber 98: 1531; c) deStevens G, Smolisnky B, Dorfman L (1964) J Org Chem 29: 1115; d) Erian AW (1999) J Prakt Chem, 341; e) Greenhill JV, Hanaee J, Steel PJ (1990) J Chem Soc Perkin Trans 1, 1869; f) Carney RWJ, Wojtkunski J, Fechtig B, Puckett RT, Biffar B, deStevens G (1971) J Org Chem 36: 2602; g) Uher M, Ilavský D, Foltín J, Škvarenivá K (1981) Collect Czech Chem Commun 46: 3128; h) El-Dean AMK, Abdel-Monea ME (2002) J Chin Chem Soc 49: 1057

[6] For ${ }^{1} \mathrm{H}$ NMR data of $3 \mathrm{a}$ at $50^{\circ} \mathrm{C}$ see: Macháčev V, El-Bahaie S, Štěrba V (1981) Collect Czech Chem Commun 46: 256

[7] Consumption of $\mathbf{3}$ is easily followed because the solution changes its color from red to yellow

[8] Farrugia LJ (1997) J Appl Cryst 30: 565

[9] Missio L, Braibante HS, Braibante MEF (1996) J Heterocyclic Chem 33: 1243

[10] a) Braibante MEF, Braibante HS, Missio L, Andricopulo A (1994) Synthesis, 898; b) Braibante MEF, Braibante, HS, Salvatore SJSA (1990) Quim Nova 13: 67; c) Braibante HS, Braibante MEF, Rosso GB, Oriques DA (2003) J Braz Chem Soc 14: 994; d) Braibante MEF, Braibante HS, Morel AF, Costa CC, Lima MG (2006) J Braz Chem Soc 17: 184

[11] Kusucu C, Rapino B, McDermott L, Hadley S (2004) J Clin Microbiol 42: 1224

[12] Enraf-Nonius (1993) $C A D-4 / P C 1.2$ Enraf-Nonius, Delft, The Netherlands

[13] Sheldrick GM (1997) SHELXS97 and SHELXL9 Program for Crystal Structure Refinement; University of Göttingen, Germany 